\title{
Phylogenetic relationships of some spirurine nematodes (Nematoda: Chromadorea: Rhabditida: Spirurina) parasitic in fishes inferred from SSU rRNA gene sequences
}

\author{
Eva Černotíková ${ }^{1,2}$, Aleš Horák ${ }^{1}$ and František Moravec ${ }^{1}$ \\ ${ }^{1}$ Institute of Parasitology, Biology Centre of the Academy of Sciences of the Czech Republic, Branišovská 31, 37005 České \\ Budějovice, Czech Republic; \\ ${ }^{2}$ Faculty of Science, University of South Bohemia, Branišovská 31, 37005 České Budějovice, Czech Republic
}

\begin{abstract}
Small subunit rRNA sequences were obtained from 38 representatives mainly of the nematode orders Spirurida (Camallanidae, Cystidicolidae, Daniconematidae, Philometridae, Physalopteridae, Rhabdochonidae, Skrjabillanidae) and, in part, Ascaridida (Anisakidae, Cucullanidae, Quimperiidae). The examined nematodes are predominantly parasites of fishes. Their analyses provided well-supported trees allowing the study of phylogenetic relationships among some spirurine nematodes. The present results support the placement of Cucullanidae at the base of the suborder Spirurina and, based on the position of the genus Philonema (subfamily Philoneminae) forming a sister group to Skrjabillanidae (thus Philoneminae should be elevated to Philonemidae), the paraphyly of the Philometridae. Comparison of a large number of sequences of representatives of the latter family supports the paraphyly of the genera Philometra, Philometroides and Dentiphilometra. The validity of the newly included genera Afrophilometra and Caranginema is not supported. These results indicate geographical isolation has not been the cause of speciation in this parasite group and no coevolution with fish hosts is apparent. On the contrary, the group of South-American species of Alinema, Nilonema and Rumai is placed in an independent branch, thus markedly separated from other family members. Molecular data indicate that the skrjabillanid subfamily Esocineminae (represented by Esocinema bohemicum) should be either elevated to the rank of an independent family or Daniconematidae (Mexiconema africanum) should be decreased to Daniconematinae and transferred to the family Skrjabillanidae. Camallanid genera Camallanus and Procamallanus, as well as the subgenera Procamallanus and Spirocamallanus are confirmed to be paraphyletic. Paraphyly has also been found within Filarioidea, Habronematoidea and Thelazioidea and in Cystidicolidae, Physalopteridae and Thelaziidae. The results of the analyses also show that Neoascarophis, Spinitectus and Rhabdochona are monophyletic, in contrast to the paraphyletic genus Ascarophis. They further confirm the independence of two subgenera, Rhabdochona and Globochona, in the genus Rhabdochona. The necessity of further studies of fish-parasitizing representatives of additional nematode families not yet studied by molecular methods, such as Guyanemidae, Lucionematidae or Tetanonematidae, is underscored.
\end{abstract}

Keywords: Nematoda, Spirurina, SSU rRNA, phylogeny, taxonomy

The present phylum Nematoda (reported as the order Nematoides by Rudolphi 1808) represents a large group of metazoan invertebrates, including animal parasites, free-living nematodes and plant parasites. Traditional classification systems of nematodes including those parasitic in vertebrates (e.g., Chitwood 1933, 1950, Yamaguti 1961, Ivashkin et al. 1971, Anderson et al. 1974-1983, 2009, Gibbons 2010), have solely been based on morphological characters and they often significantly differ from each other.

Chitwood (1933) established the order Spirurida as a part of the subclass Secernentea within his classification system of the class Nematoda. This class is composed of two suborders, Camallanina and Spirurina. Whereas the former contains only the superfamilies Camallanoi- dea and Dracunculoidea (Anguillicoloidea has recently been singled out from Dracunculoidea as a basal group to Spirurida - see Moravec 2006, Wijová et al. 2006, present data), the latter includes ten superfamilies (Acuarioidea, Aproctoidea, Diplotriaenoidea, Filarioidea, Gnathostomatoidea, Habronematoidea, Physalopteroidea, Rictularioidea, Spiruroidea and Thelazioidea) (Chabaud 1974, Gibbons 2010). According to the present taxonomy based on morphology, the order Spirurida contains 25 (Anderson 2000) or 28 (Moravec et al. 1998) families.

Camallanoidea contains only one family Camallanidae, whereas Dracunculoidea includes eight families of which, except for Dracunculidae and Micropleuridae, all comprise exclusively fish parasites: Daniconematidae, Guyanemidae, Lucionematidae, Philometridae, Skrja- 
billanidae and Tetanonematidae. Camallanina contains parasites of all classes of vertebrates (Chabaud 1974). Whereas members of Camallanoidea are gastrointestinal parasites of cold-blooded vertebrates, those of Dracunculoidea are parasitic in a variety of host tissues and cavities in both cold- and warm-blooded vertebrates (Anderson 2000). Intermediate hosts of Camallanina representatives are aquatic crustaceans, mostly Copepoda, less often Branchiura or Ostracoda (Moravec 2004).

Spirurina contains ten superfamilies (see above), of which members of four (Gnathostomatoidea, Habronematoidea, Physalopteroidea and Thelazioidea) are also parasitic in freshwater, brackish-water and marine fishes, whereas the six remaining superfamilies are represented by parasites of amphibians, reptiles, birds and mammals including man. Parasites of fishes belong to four families: Gnathostomatidae (Gnathostomatoidea), Physalopteridae (Physalopteroidea), Cystidicolidae (Habronematoidea) and Rhabdochonidae (Thelazioidea) (Moravec 2007). The life cycles of spirurine nematodes are noted for considerable variations. Intermediate hosts are invertebrates, in fish parasites mainly crustaceans and aquatic insects (copepods only in Gnathostomatoidea) (Chabaud 1974, Anderson 2000, Moravec 2007). Some species exhibit precocious larval development or even maturation in the body of the intermediate host. Paratenic and postcyclic parasitisms are fairly common in these nematodes (Moravec 1994). Representatives of this suborder are gastrointestinal or tissues parasites of all classes of vertebrates.

At the end of the 1990's, the first extensive molecularphylogenetic analyses of these parasites were published (Blaxter et al. 1998), which placed spirurid nematodes in a separate branch designated as 'clade III' (Blaxter et al. 1998, Nadler et al. 2007). Later, in their newly proposed classification system, De Ley and Blaxter (2002, 2004) named it the suborder Spirurina, including the groups Ascaridomorpha, Gnathostomatomorpha, Oxyuridomorpha, Rhigonematomorpha, Spiruromorpha and Dracunculoidea (the latter as incertae sedis). These groups mostly correspond to the morphologically-established orders Ascaridida (Ascaridomorpha), Oxyurida (Oxyuromorpha), Rhigonematida (Rhigonematomorpha) and Spirurida (Gnathostomatomorpha, Spiruromorpha, Dracunculoidea). According to De Ley and Blaxter (2004), Spirurina includes 21 superfamilies, 9 of which contain fish parasites (Moravec 2007). However, the following studies suggest that the arrangement within this group will further change as the number of molecular data increases (Wijová et al. 2006, Nadler et al. 2007).

The latest molecular studies including a large number of examined species have revealed the paraphyly of numerous groups within the suborder Spirurina after De Ley and Blaxter (2002) and even inside 'clade III' itself (Nadler et al. 2007). This result is not surprising and, as Wijová et al. (2006) and Nadler et al. (2007) remarked, the solution of phylogenetic interrelationships in this group requires significantly more examined species as well as the sequencing of additional genes to obtain statistically better supported conclusions.

The results of the evaluation of phylogenetic relationships within the nematode suborder Spirurina of De Ley and Blaxter (2002), inferred from SSU rRNA gene sequences mainly of species of the families Cystidicolidae, Philometridae and Rhabdochonidae parasitizing fishes, are presented herein.

\section{MATERIALS AND METHODS}

Taxa sampled for phylogenetic analyses are listed in Table 1 , whereas those for which sequences have been obtained from GenBank are shown in Table 2. Prior to DNA extraction, collected specimens were stored in $70-99 \%$ ethanol. Genomic DNA was isolated using standard proteinase $\mathrm{K}$ treatment and phenol-chloroform extraction (Sambrook and Russell 2001). The extraction was stored at $-20^{\circ} \mathrm{C}$ until further use. About 10 ng of genomic DNA was used for PCR amplification of the SSU rRNA gene using either the primer pair PhilonemaF and PhilPCRr (Table 3) or separately in three overlapping fragments: the first fragment: the forward primer PhilonemaF in combination with the reverse primer ameb620r; the second fragment: the forward primer WF400 and the reverse primer WR800; the third fragment: the forward primer ameb620f and the reverse primer PhilPCRr. PCR cycling parameters included denaturation at $94^{\circ} \mathrm{C}$ for $5 \mathrm{~min}$, followed by 35 cycles of $94^{\circ} \mathrm{C}$ for $40 \mathrm{sec}, 50^{\circ} \mathrm{C}$ for $40 \mathrm{sec}, 72^{\circ} \mathrm{C}$ for $2 \mathrm{~min}$, followed by a final elongation at $72{ }^{\circ} \mathrm{C}$ for $10 \mathrm{~min}$. Most SSU PCR products were used for direct sequencing following enzymatic treatment using exonuclease I and shrimp alkaline phosphatase or some products were cloned before sequencing. For cloning, PCR products were purified from gel using the QIAquick Gel Extraction Kit (QIAGEN) and cloned into the pGEM-T Easy Vector II (Promega). Both strands were sequenced using a Beckman Coulter Automated Sequencer.

The resulting sequences were refined using the Editseq and Seqman programs (Dnastar). The sequence alignments were created using Mafft Multiple alignment program for amino acid or nucleotide sequences) ver. 6 (http://align.bmr.kyushu-u.ac.jp/ mafft/online/server/) (Katoh et al. 2002) and ambiguous sites were manually edited in BioEdit ver. 7.0.5.2 (Hall 1999).

The 'clade III' dataset (results of analysis are shown in Fig.1) was created from 104 SSU rRNA sequences from Table 1 and Table 2 and was rooted by 5 taxa according to Meldal et al. (2007): Areolaimida (Anaplectus sp., Plectus aquatilis, Tylocephalus auriculatus) and Rhabditida (Brevibucca sp., Myolaimus sp.). To test the monophyly of 'clade III' (recently infirmed by Nadler et al. 2007) we also constructed 'Chromadoria' dataset (Fig. 3), which included 51 representatives of the group Chromadoria (from which 10 taxa represent 'clade III') according to Meldal et al. (2007). The phylogenetic tree was rooted with the sequences of related groups Dorylaimia: Dorylaimida (Aporcelameillus obtusicaudatus), Mononchida (Prionchulus muscorum), Trichocephalida (Trichinella spiralis) and Enoplia: Enoplida (Alaimus sp.). The use of the broadest taxon sampling possible is usually recommended in phylogenetics. However, in the case of markers with hyper-variable regions, such as SSU 
Table 1. Specimen, taxonomic (traditional classification), host, and locality information for nematodes from which the small subunit rRNA gene was sequenced within the frame of this study.

\begin{tabular}{|c|c|c|c|c|c|}
\hline Species name & Traditional classification & Host & & Locality & $\begin{array}{l}\text { GenBank } \\
\text { accession } \\
\text { number }\end{array}$ \\
\hline Ascarophis (Dentiascarophis) adioryx & Cystidicolidae/Habronematoidea & Sargocentron spiniferum & Marine fish & New Caledonia & JF803930 \\
\hline Afrophilometra hydrocyoni & Philometridae/Dracunculoidea & Hydrocynus forskahlii & Freshwater fish & Kenya & JF803946 \\
\hline Camallanus hypophthalmichthys & Camallanidae/Camallanoidea & Aristichthys nobilis & Freshwater fish & China & JF803915 \\
\hline Caranginema americanum & Philometridae/Dracunculoidea & Caranx hippos & Marine fish & Florida (USA) & JF803939 \\
\hline Cucullanus baylisi & Cucullanidae/Seuratoidea & Synodontis sp. & Freshwater fish & Sudan & JF803935 \\
\hline Cystidicola farionis & Cystidicolidae/Habronematoidea & $\begin{array}{l}\text { Salmo trutta fario } \times \\
\text { Salmo marmorata }\end{array}$ & Freshwater fish & Italy & JF803919 \\
\hline Esocinema bohemicum & Skrjabillanidae/Dracunculoidea & Esox lucius & Freshwater fish & Russia & JF803917 \\
\hline Goezia spinulosa & Raphidascarididae/Ascaridoidea & Arapaima gigas & Freshwater fish & Brazil & JF803924 \\
\hline Heliconema longissimum & Physalopteridae/Physalopteroidea & Anguilla japonica & Freshwater fish & Japan & JF803949 \\
\hline Heliconema longissimum & Physalopteridae/Physalopteroidea & Anguilla sp. & Freshwater fish & Madagascar & JF803926 \\
\hline Metabronema magnum & Cystidicolidae/Habronematoidea & Gnathonodon speciosus & Marine fish & New Caledonia & JF803918 \\
\hline Mexiconema africanum & Daniconematidae/Dracunculoidea & Auchenoglanis occidentalis & Freshwater fish & Kenya & JF803947 \\
\hline Neoascarophis longispicula & Cystidicolidae/Habronematoidea & $\begin{array}{l}\text { Coryphaenoides } \\
\text { mediterraneus }\end{array}$ & Marine fish & $\begin{array}{l}\text { Atlantic ocean } \\
\text { (Middle Ridge) }\end{array}$ & JF803921 \\
\hline Paraquimperia africana & Quimperiidae/Seuratoidea & Anguilla marmorata & Freshwater fish & South Africa & JF803925 \\
\hline Philometra bagri & Philometridae/Dracunculoidea & Bagrus bajad & Freshwater fish & Kenya & JF803948 \\
\hline Philometra brevispicula & Philometridae/Dracunculoidea & Lutjanus griseus & Marine fish & Florida (USA) & JF803943 \\
\hline Philometra diplectri & Philometridae/Dracunculoidea & Diplectrum formosum & Marine fish & Florida (USA) & JF803942 \\
\hline Philometra floridensis & Philometridae/Dracunculoidea & Sciaenops ocellatus & Marine fish & USA & JF803928 \\
\hline Philometra gymnosardae & Philometridae/Dracunculoidea & Gymnosarda unicolor & Marine fish & Maldives & JF803916 \\
\hline Philometra lati & Philometridae/Dracunculoidea & Lates niloticus & Freshwater fish & Kenya & JF803945 \\
\hline Philometra morii & Philometridae/Dracunculoidea & Epinephelus morio & Marine fish & Florida (USA) & JF803933 \\
\hline Philometra ocularis & Philometridae/Dracunculoidea & Epinephelus areolatus & Marine fish & New Caledonia & JF803929 \\
\hline Philometra saltatrix & Philometridae/Dracunculoidea & Pomatomus saltatrix & Marine fish & $\begin{array}{l}\text { South Carolina } \\
\text { (USA) }\end{array}$ & JF803920 \\
\hline Philometra sp. & Philometridae/Dracunculoidea & Mycteroperca microlepis & Marine fish & Florida (USA) & JF803940 \\
\hline Philometra spiriformis & Philometridae/Dracunculoidea & Lates niloticus & Freshwater fish & Kenya & JF803944 \\
\hline Philometroides grandipapillatus & Philometridae/Dracunculoidea & Caranx hippos & Marine fish & Florida (USA) & JF803941 \\
\hline $\begin{array}{l}\text { Procamallanus (Spirocamallanus) } \\
\text { fulvidraconis }\end{array}$ & Camallanidae/Camallanoidea & Pelteobagrus fulvidraco & Freshwater fish & China & JF803914 \\
\hline $\begin{array}{l}\text { Procamallanus (Procamallanus) } \\
\text { laeviconchus }\end{array}$ & Camallanidae/Camallanoidea & Synodontis schall & Freshwater fish & Sudan & JF803934 \\
\hline $\begin{array}{l}\text { Procamallanus (Procamallanus) an- } \\
\text { nulatus }\end{array}$ & Camallanidae/Camallanoidea & Siganus lineatus & Marine fish & New Caledonia & JF803932 \\
\hline $\begin{array}{l}\text { Procamallanus (Spirocamallanus) } \\
\text { monotaxis }\end{array}$ & Camallanidae/Camallanoidea & Lethrinus genivittatus & Marine fish & New Caledonia & JF803931 \\
\hline $\begin{array}{l}\text { Procamallanus (Spirocamallanus) } \\
\text { rarus }\end{array}$ & Camallanidae/Camallanoidea & Callophysus macropterus & Freshwater fish & Peru & JF803912 \\
\hline $\begin{array}{l}\text { Rhabdochona (Rhabdochona) hellichi } \\
\text { hellichi }\end{array}$ & Rhabdochonidae/Thelazioidea & Barbus barbus & Freshwater fish & Czech Republic & JF803913 \\
\hline $\begin{array}{l}\text { Rhabdochona (Rhabdochona) hellichi } \\
\text { turkestanica }\end{array}$ & Rhabdochonidae/Thelazioidea & Schizothorax sp. & Freshwater fish & India & JF803937 \\
\hline Rhabdochona (Rhabdochona) hospeti & Rhabdochonidae/Thelazioidea & Tor sp. & Freshwater fish & India & JF803938 \\
\hline Rhabdochona (Globochona) mazeedi & Rhabdochonidae/Thelazioidea & Clupisoma garua & Freshwater fish & India & JF803936 \\
\hline Rumai rumai & Philometridae/Dracunculoidea & Arapaima gigas & Freshwater fish & Brazil & JF803923 \\
\hline Salmonema ephemeridarum & Cystidicolidae/Habronematoidea & Ephemera danica & Mayfly & Czech Republic & JF803927 \\
\hline Spinitectus tabascoensis & Cystidicolidae/Habronematoidea & Ictalurus meridionalis & Freshwater fish & Mexico & JF803922 \\
\hline
\end{tabular}

rRNA, a considerable amount of data may potentionally be discarded prior to analysis due to their incapacity to be aligned unambiguously. This situation is usually caused by a high divergence between compared sequences. For example, the "clade III' dataset with broad sampling was reduced from 2452 to 1562 nucleotides. On the other hand, the 'Camallanoidea' dataset (see bellow) contained 1660 nucleotides (of 1802) after the ambiguous-site removal. To get deeper insight into the relationships of some groups of our interest, we also performed analyses on a subset of four 'smaller' datasets. Camallanus oxycephalus, Camallanus hypophthalmichthys, Procamallanus pintoi were used as outgroups in the 'Dracunculoidea' dataset, concentrat- ing on the dracunculoid nematodes (results shown in Fig. 2). Dracunculus insignis, Dracunculus medinensis and Dracunculus oesophageus were used as outgroups in the 'Philometridae' dataset (Fig. 4), where we included also shorter sequences of some philometrids ( $950 \mathrm{bp}$ ) from GenBank. Philonema oncorhynchi was used as an outgroup in the 'Camallanoidea' dataset (Fig. 4) and Philonema oncorhynchi and Camallanus cotti were used as outgroups in the 'Spirurina' dataset (Fig. 5). All datasets are available upon request from the corresponding author.

Maximum likelihood (ML) trees were calculated under the GTR $+\Gamma+$ I model of evolution using PHYML 2.4.2. This model of evolution was chosen according to the Akaike criterion as 
Table 2. List of nematode species from which the sequence of small subunit rRNA gene was retrieved from GenBank, with traditional classification and GenBank accession number.

\begin{tabular}{|c|c|c|c|c|c|}
\hline Species name & Traditional classification & $\begin{array}{l}\text { GenBank } \\
\text { accession } \\
\text { number }\end{array}$ & Species name & Traditional classification & $\begin{array}{l}\text { GenBank } \\
\text { accession } \\
\text { number }\end{array}$ \\
\hline Acanthocheilonema viteae & Onchocercidae/Filarioidea & DQ094171 & Paraspidodera sp. & Aspidoderidae/Heterakoidea & AF083005 \\
\hline Aduncospiculum halicti & Diplogasteridae/Diplogasterida & U61759 & Philometra clavaeceps & Philometridae/Dracunculoidea & DQ076686 \\
\hline Alaimus sp. & Alaimidae/Oxystominoidea & AJ966514 & Philometra cyprinirutili & Philometridae/Dracunculoidea & DQ442675 \\
\hline Alinema amazonicum & Philometridae/Dracunculoidea & DQ442672 & Philometra fujimotoi & Philometridae/Dracunculoidea & DQ076680 \\
\hline Anaplectus sp. & Plectidae/Plectoidea & AJ966473 & Philometra lateolabracis & Philometridae/Dracunculoidea & FJ161972 \\
\hline Anguillicola crassus & Anguillicolidae/Anguillicoloidea & DQ490223 & Philometra madai & Philometridae/Dracunculoidea & FJ161974 \\
\hline Aphelenchus avenae & Aphelenchidae/Aphelenchoidea & AF036586 & Philometra nemipteri & Philometridae/Dracunculoidea & FJ161975 \\
\hline Aporcelaimellus ob- & Aporcelaimidae/Dorylaimoidea & DQ141212 & Philometra obturans & Philometridae/Dracunculoidea & AY852267 \\
\hline tusicaudatus & & & Philometra ovata & Philometridae/Dracunculoidea & DQ442677 \\
\hline Ascaris lumbricoides & Ascarididae/Ascaridoidea & U94366 & Philometra sawara & Philometridae/Dracunculoidea & FJ161973 \\
\hline Ascarophis arctica & Cystidicolidae/Habronematoidea & DQ094172 & Philometra sciaenae & Philometridae/Dracunculoidea & FJ161971 \\
\hline Axonolaimus helgolandicus & Axonolaimidae/Axonolaimoidea & AY854232 & Philometra sp. & Philometridae/Dracunculoidea & DQ442674 \\
\hline Boleodorus thylactus & Tylenchidae/Tylenchoidea & AY993976 & Philometroides carassii & Philometridae/Dracunculoidea & DQ076683 \\
\hline Brevibucca sp. & Brevibuccidae/Panagrolaimoidea & AF202163 & Philometroides cyprini & Philometridae/Dracunculoidea & DQ076688 \\
\hline Brugia malayi & Onchocercidae/Filarioidea & AF036588 & Philometroides fulvidraconi & Philometridae/Dracunculoidea & DQ076684 \\
\hline Brumptaemilius justini & Rhigonematida & AF036589 & Philometroides & Philometridae/Dracunculoidea & DQ076681 \\
\hline Bunonema franzi & Bunonematidae/Bunonematoidea & AJ966477 & ganzhounensis & & \\
\hline Caenorhabditis elegans & Rhabditidae/Rhabditoidea & X03680 & Philometroides & Philometridae/Dracunculoidea & DQ076687 \\
\hline Calomicrolaimus & Microlaimidae/Richtersioidea & AY854218 & & & \\
\hline parahonestus & & & Philometroides sanguineus & Philometridae/Dracunculoidea & DQ442676 \\
\hline Camallanus cotti & Camallanidae/Camallanoidea & EF180071 & Philometroides seriolae & Philometridae/Dracunculoidea & FJ155811 \\
\hline Camallanus lacustris & Camallanidae/Camallanoidea & DQ442663 & Philonema oncorhynchi & Philometridae/Dracunculoidea & DQ442670 \\
\hline Camallanus oxycephalus & Camallanidae/Camallanoidea & DQ503463 & Philonema sp. & Philometridae/Dracunculoidea & U81574 \\
\hline Camallanus sp. & Camallanidae/Camallanoidea & DQ442664 & Plectus aquatilis & Plectidae/Plectoidea & AF036602 \\
\hline Catanema sp. & Desmodoridae/Desmodorida & Y16912 & Physaloptera alata & Physalopteridae/Physalopteroidea & AY702703 \\
\hline Cervidellus alutus & Cephalobidae/Cephaloboidea & AF202152 & Physaloptera sp. & Physalopteridae/Physalopteroidea & EF180065 \\
\hline Chromadoria nudicapitata & Chromadoridae/Chromadorida & AY854205 & Pratylenchus thornei & Pratylenchidae/Tylenchoidea & AJ966499 \\
\hline Clavinema parasiluri & Philometridae/Dracunculoidea & DQ076682 & Procamallanus pacificus & Camallanidae/Camallanoidea & DQ442665 \\
\hline Criconema sp. & Criconematidae/Criconematoidea & AJ966480 & Procamallanus pintoi & Camallanidae/Camallanoidea & DQ442666 \\
\hline Cruzia americana & Kathlaniidae/Cosmocercoidea & U94371 & Procamallanus rebecae & Camallanidae/Camallanoidea & DQ442667 \\
\hline Cyartonema elegans & Cyartonematidae/Monhysterida & AY854203 & Prionchulus muscorum & Mononchidae/Mononchoidea & AJ966500 \\
\hline Cyatholaimus sp. & Cyatholaimidae/Chromadorida & AY854213 & Raillietnema sp. & Cosmocercidae/Cosmocercoidea & DQ503461 \\
\hline Cyrnea mansioni & Habronematidae/Habronematoidea & AY702701 & Rhabdochona denudata & Rhabdochonidae/Thelazioidea & DQ442659 \\
\hline Daptonema procerus & Xyalidae/Monhysterida & AF047889 & Rhabditis myriophila & Rhabditidae/Rhabditoidea & U81588 \\
\hline Dentiphilometra monopteri & Philometridae/Dracunculoidea & DQ076685 & Rhabditoides inermis & Rhabditidae/Rhabditoidea & AF082996 \\
\hline Dentiphilometra sp. & Philometridae/Dracunculoidea & DQ442673 & Rhigonema thysanophora & Rhigonematidae/Rhigonematoidea & EF180067 \\
\hline Dentostomella sp. & Heteroxynematidae/Oxyuroidea & AF036590 & Rondonia rondoni & Atractidae/Rhabditida & DQ442679 \\
\hline Desmodora ovigera & Desmodoridae/Desmodorida & Y16913 & Sabatieria punctata & Comesomatidae/Monhysterida & AY854236 \\
\hline Desmolaimus zeelandicus & Linhomoetidae/Monhysterida & AY854229 & Scutellonema bradys & Hoplolaimidae/Tylenchoidea & AJ966504 \\
\hline Dichromadora sp. & Chromadoridae/Chromadorida & AY854209 & Serratospiculum tendo & Diplotriaenidae/Diplotriaenoidea & AY702704 \\
\hline Dirofilaria immitis & Onchocercidae/Filarioidea & $\mathrm{AF} 036638$ & Skrjabillanus scardinii & Skrjabillanidae/Dracunculoidea & DQ442669 \\
\hline Dracunculus insignis & Dracunculidae/Dracunculoidea & AY947719 & Sphaerolaimus hirsutus & Sphaerolaimidae/Monhysterida & AY 854228 \\
\hline Dracunculus medinensis & Dracunculidae/Dracunculoidea & AY852268 & Spinitectus carolini & Cystidicolidae/Habronematoidea & DQ503464 \\
\hline Dracunculus oesophageus & Dracunculidae/Dracunculoidea & AY852269 & Spirocamallanus istiblenni & Camallanidae/Camallanoidea & EF180076 \\
\hline Echinuria borealis & Acuariidae/Acuarioidea & EF180064 & Spirocamallanus rarus & Camallanidae/Camallanoidea & DQ494195 \\
\hline Geocenamus quadrifer & Belonolaimidae/Tylenchoidea & AY993977 & Spirocerca lupi & Thelaziidae/Thelazioidea & AY751497 \\
\hline Gnathostoma binucleatum & Gnathostomatidae/Gnathostomatoidea & Z96946 & Strongyloides ratti & Strongyloididae/Panagrolaim & U81581 \\
\hline Gnathostoma turgidum & Gnathostomatidae/Gnathostomatoidea & Z96948 & Strongylus equinus & Strongylidae/Strongyloidea & DQ094176 \\
\hline Goezia pelagia & Raphidascarididae/Ascaridoidea & U94372 & Subanguina radicicola & Anguinidae/Tylenchoidea & AF202164 \\
\hline Heterakis sp. & Heterakidae/Heterakoidea & AF083003 & Synhimantus laticeps & Acuariidae/Acuarioidea & EU004818 \\
\hline Heterakis gallinarum & Heterakidae/Heterakoidea & DQ503462 & Teratocephalus lirellus & Teratocephalidae/Teratocephaloidea & AF036607 \\
\hline Isolaimium $\mathrm{sp}$. & Isolaimidae/Isolaimoidea & AY919142 & Teratorhabditis synpapillata & Rhabditidae/Rhabditoidea & AF083015 \\
\hline Loa loa & Onchocercidae/Filarioidea & DQ094173 & Terschellingia longicaudata & Linhomoetidae/Monhysterida & AY854230 \\
\hline Margolisianum bulbosum & Philometridae/Dracunculoidea & $\mathrm{AB} 185161$ & Terranova scoliodontis & Anisakidae/Ascaridoidea & DQ442661 \\
\hline Meloidogyne incognita & Meloidogynidae/Tylenchoidea & U81578 & Tetrameres fissipina & Tetrameridae/Habronematoidea & EF180077 \\
\hline Micropleura australiensis & Micropleuridae/Dracunculoidea & DQ442678 & Thelazia lacrymalis & Thelaziidae/Thelazioidea & DQ503458 \\
\hline Molnaria intestinalis & Skrjabillanidae/Dracunculoidea & DQ442668 & Toxocara canis & Ascarididae/Ascaridoidea & AF036608 \\
\hline Monoposthia costata & Monoposthiidae/Desmodorida & AY854221 & Toxocara canis & Ascarididae/Ascaridoidea & U94382 \\
\hline Myolaimus sp. & Myolaimidae/Myolaimoidea & U81585 & Tridentulus sp. & Monhysteridae/Monhysterida & AJ966507 \\
\hline Neoascarophis macrouri & Cystidicolidae/Habronematoidea & DQ442660 & Trichinella spiralis & Trichinellidae/Trichocephalida & U60231 \\
\hline Nilonema senticosum & Philometridae/Dracunculoidea & DQ442671 & Truttaedacnitis truttae & Cucullanidae/Seuratoidea & EF180063 \\
\hline Nippostrongylus brasiliensis & Heligmonellidae/Trichostrongyloidea & AF036597 & Turgida torresi & Physalopteridae/Physalopteroidea & EF180069 \\
\hline Onchocercidae gen. sp. & Onchocercidae/Filarioidea & DQ103704 & Turgida turgida & Physalopteridae/Physalopteroidea & DQ503459 \\
\hline Oxyuris equi & Oxyuridae/Oxyuroidea & EF180062 & Tylenchidae gen. sp. & Tylenchidae/Tylenchoidea & AY854241 \\
\hline \multirow[t]{2}{*}{ Panagrolaimus sp. } & Panagrolaimidae/Panagrolaimoidea & U81579 & Tylocephalus auriculatus & Plectidae/Plectoidea & AF202155 \\
\hline & & & Zeldia punctata & Cephalobidae/Cephaloboidea & U61760 \\
\hline
\end{tabular}


Table 3. List of primers used for PCR and sequencing.

\begin{tabular}{|c|c|c|}
\hline Primer & Primer sequence 5 '- 3 , & Usage \\
\hline PhilonemaF & GCC TAT AAT GGT GAA ACC GCG AAC & $\begin{array}{l}\text { PCR and } \\
\text { sequencing }\end{array}$ \\
\hline PhilPCRr & CCG GTT CAA GCC ACT GCG ATT A & $\begin{array}{l}\text { PCR and } \\
\text { sequencing }\end{array}$ \\
\hline WF400 & GCG CAA ATT ACC CAC TCT & $\begin{array}{l}\text { PCR and } \\
\text { sequencing }\end{array}$ \\
\hline WR400 & CAA CTT CAT GCG GCT GAA & Sequencing \\
\hline ameb620f & GCC AGC ACC CGC GGT AAT TCC & $\begin{array}{l}\text { PCR and } \\
\text { sequencing }\end{array}$ \\
\hline ameb620r & GGA ATT ACC GCG GGT GCT GGC & $\begin{array}{l}\text { PCR and } \\
\text { sequencing }\end{array}$ \\
\hline WF760 & GCC TGA ATA CTC GTG CAT & Sequencing \\
\hline WR800 & GGT ATC GTT TAC GGT CAG & $\begin{array}{l}\text { PCR and } \\
\text { sequencing }\end{array}$ \\
\hline Phil1200F & CCG TGA GGA TTG ACA GAT TGA GAG C & Sequencing \\
\hline Phil1200R & CCG CGG CTG CTG GCA CCA GAC TT & Sequencing \\
\hline WF1550 & CCT AGT AAG TGT GAG TCA & Sequencing \\
\hline WR1600 & CAG ACT CAC CAA TTG ACG & Sequencing \\
\hline
\end{tabular}

implemented in Modeltest 3.7 (Posada and Crandall 1998). For Bayesian inference (BI), we ran two chains for a variable number of generations (for details see figure legend) under the GTR $+\Gamma+\mathrm{I}$ and default priors in MrBayes 3.1.2 (Huelsenbeck et al. 2001). After the check for convergence, we discarded the first $25 \%$ as a burn-in and the rest was used for topology and posterior probability reconstruction. Branching support was estimated using non-parametric bootstraping in case of ML (number of replications varied in between the datasets, see figure legend for details) or posterior probability (BI). Nodes were considered to be highly supported with the boostrap value higher than 90 and posterior probability equal to 1.0 ; moderately supported with the bootstrap value $70-90$ and posterior probability higher than 0.94 .

When our topology was not congruent with conventional classification (i.e. we found some groups to be poly/paraphyletic), we forced monophyly of respective groups, recomputed phylogeny under the constraint using RAxML 7.2.8 (Stamatakis 2006) and performed approximately-unbiased test (au-test, Shimodaira 2004) as implemented in Consel (Shimodaira and Hasegawa 2001).

\section{RESULTS}

Thirty-eight new SSU rRNA sequences of nematodes (ranging from 1629 to $1920 \mathrm{bp}$ ) were used along with 126 of those from previously published taxa for phylogenetic analyses. The most extensive analysis comprises 109 taxa from which 104 species represent 'clade III' (Fig. 1). The superfamily Seuratoidea appears at the base of the phylogenetic tree, being represented by the family Quimperiidae (Paraquimperia africana) on the first branch and the family Cucullanidae (Cucullanus baylisi and Truttaedacnitis truttae) on the second branch. The position of Quimperiidae, which constitutes a sister group to the well-promoted cluster of the remaining representatives of Spirurina according to De Ley and Blaxter (2002), is supported only by poor posterior probability and low bootstrap. To address possible paraphyly of the whole 'clade
III', we constructed the tree into which selected representatives of the group Chromadoria were involved (Fig. 3). In this analysis, 'clade III' appears as monophyletic, but with still a relatively low statistical support.

According to the previous 'clade III' analysis (Fig. 1), Oxyurida is the only monophyletic order, whereas other orders (Ascaridida, Rhigonematida and Spirurida) are paraphyletic. Representatives of Spirurida (except for three species of two superfamilies), Ascaridida (except for four species of three superfamilies), Rhigonematida and Oxyurida form polytomy in the middle part of the tree. Most species of Spirurida rank with a cluster on the upper part of the tree and split in two morphologically and molecularly defined suborders Camallanina and Spirurina, as previously defined by Chitwood (1937). Representatives of the superfamilies Anguillicoloidea (Camallanina) and Gnathostomatoidea (Spirurina) are located on the distant branch forming a well-supported sister group to all the mentioned orders (see above), which, before dataset completion with species of the superfamily Seuratoidea, was situated at the base of the whole 'clade III' (Wijová et al. 2006).

Monophyly of the superfamily Dracunculoidea is well supported after the elevation of Anguillicolidae to the superfamily rank. The superfamily Camallanoidea (family Camallanidae), forming a sister group to Dracunculoidea, is also monophyletic. The Dracunculoidea includes monophyletic families Dracunculidae, Micropleuridae, Daniconematidae and paraphyletic Philometridae and Skrjabillanidae. The well-supported part of Philometridae forms a sister group to Dracunculidae and Micropleuridae with indefinite relationships. Fig. 2 displays the phylogenetic tree constructed from a dataset containing only representatives of Dracunculoidea and brings more detailed view on the relationships within this taxon. Polytomy is eliminated and Micropleura australiensis (Micropleuridae) forms a sister group to Dracunculidae. A sister group to the three above-mentioned families is that comprising Skrjabillanidae, Daniconematidae and partly Philometridae (Philonema sp.). Mexiconema africanum (Daniconematidae) incorporates between skrjabillanids and forms a sister group to the species Micropleura australiensis and Skrjabillanus scardinii. These three species are situated on the same branch with the part of Philometridae represented two species (Philonema sp. and Philonema oncorhynchi), which forms a sister group to the two abovementioned families.

Another two phylogenetic trees illustrate relationships in the families Philometridae and Camallanidae (Fig. 4). The former was examined within the whole superfamily Dracunculoidea in the first analysis (Fig. 2). The second phylogenetic tree in Fig. 4 is focused on only the family Camallanidae. Both these analyses support results of a previous study (Wijová et al. 2006). The genera Philometra, Philometroides and Dentiphilometra are paraphyletic. The well-supported branch with two South 


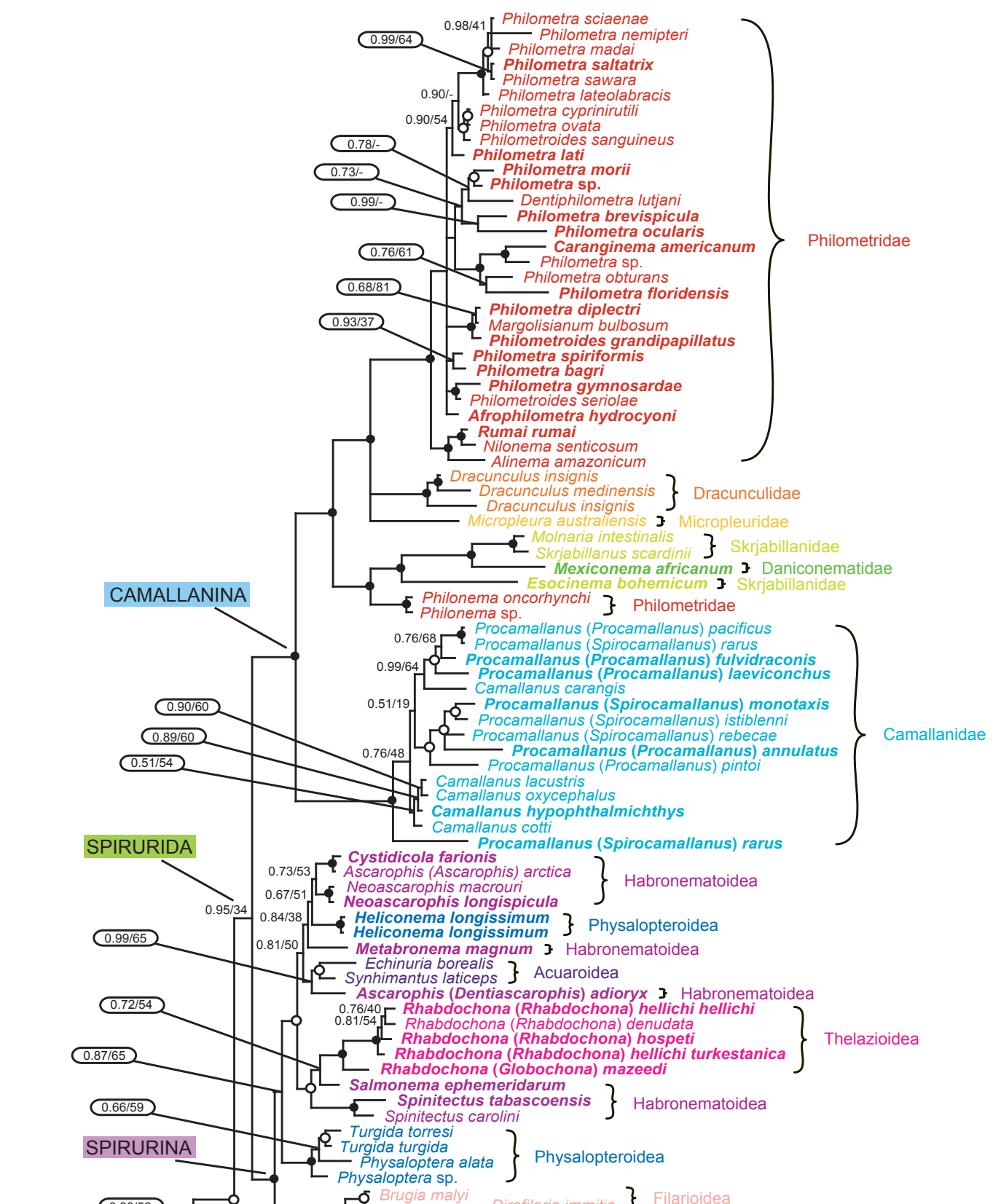

Fig. 1. Bayesian tree inferred from phylogenetic analysis of the SSU rRNA sequences dataset 'clade III' (suborder Spirurina sensu De Ley and Blaxter 2002). The first number near nodes represents Bayesian posterior probability (for $1 \times 10^{7}$ generations $\left[\right.$ burn-in $\left.=2.5 \times 10^{6}\right]$ ) and the second number is maximum likelihood (ML) bootstrap value (from 1000 replications). Newly acquired sequences are marked bold. Full circles illustrate high support (ML $>90$, $\mathrm{BI}=1.00)$ and empty circles illustrate moderate bootstrap support $(\mathrm{ML}=70-90, \mathrm{BI}=0.80-0.99)$. Branch with Brevibucca sp. is reduced by two thirds. 


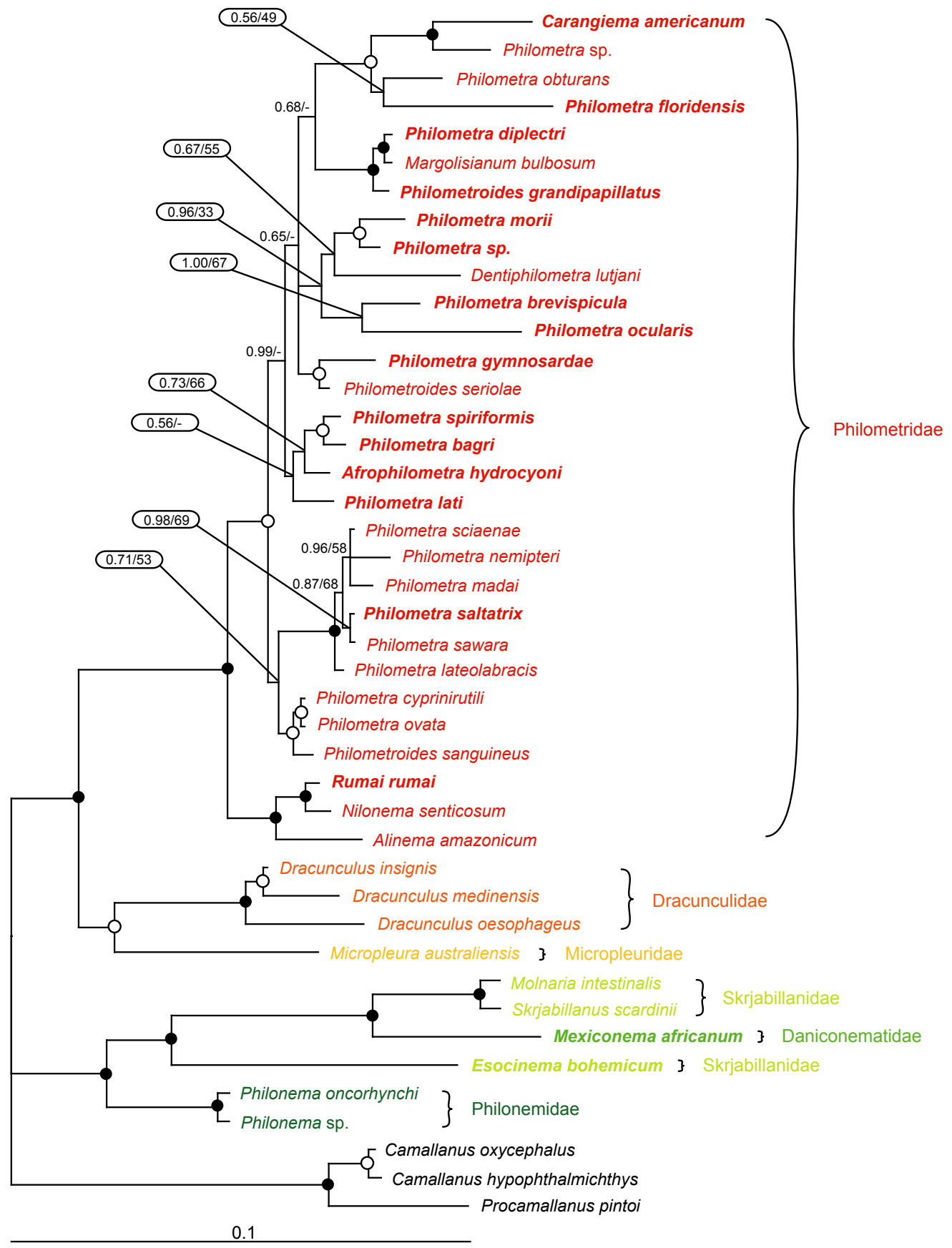

Fig. 2. Bayesian tree inferred from phylogenetic analysis of the SSU rRNA sequences dataset Dracunculoidea. The first number near nodes represents Bayesian posterior probability (for $5 \times 10^{6}$ generations [burn-in $=2 \times 10^{6}$ ) and the second number is maximum likelihood (ML) bootstrap value (from 500 replications). Newly acquired sequences are marked bold. Full circles illustrate high support $(\mathrm{ML}>90, \mathrm{BI}=1.00)$ and empty circles illustrate moderate bootstrap support $(\mathrm{ML}=70-90, \mathrm{BI}=0.80-0.99)$.

American species (Nilonema senticosum and Alinema amazonicum) separating from others is completed by the next one, Rumai rumai, which is situated on the common branch with Nilonema. It is evident from the phylogenetic tree examining relationships within the family Camallanidae that the genera Camallanus and Procamallanus, as well as the subgenera Procamallanus and Spirocamallanus are paraphyletic (Fig. 4). A sister group to the subor- der Camallanina constitutes the morphologically defined suborder Spirurina Chitwood, 1937. In one analysis, this fission is supported by a high posterior probability (0.95), while the ML analysis shows low bootstrap (34). The suborder Spirurina Chitwood, 1937 divides into two stable branches, of which the first is formed by one monophyletic superfamily Acuarioidea (family Acuariidae) and three paraphyletic superfamilies Habronematoidea, 


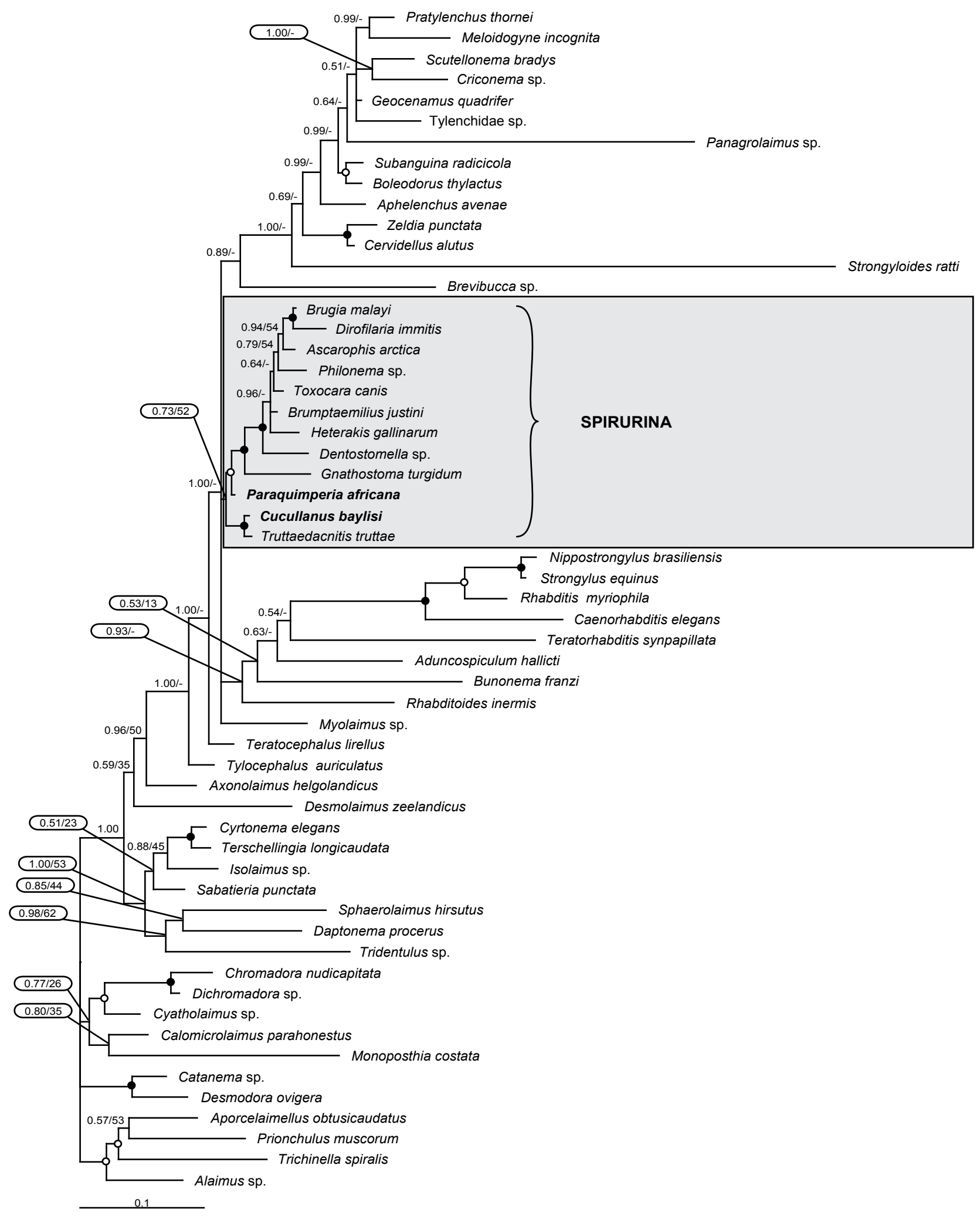

Fig. 3. Bayesian tree inferred from phylogenetic analysis of the SSU rRNA sequences dataset Chromadoria. The first number near nodes represents Bayesian posterior probability (for $5 \times 10^{6}$ generations [burn-in $\left.=1 \times 10^{6}\right]$ ) and the second number is maximum likelihood (ML) bootstrap value (from 500 replications). Newly acquired sequences are marked bold. Full circles illustrate high support $(\mathrm{ML}>90, \mathrm{BI}=1.00)$ and empty circles illustrate moderate bootstrap support $(\mathrm{ML}=70-90, \mathrm{BI}=0.80-0.99)$. 

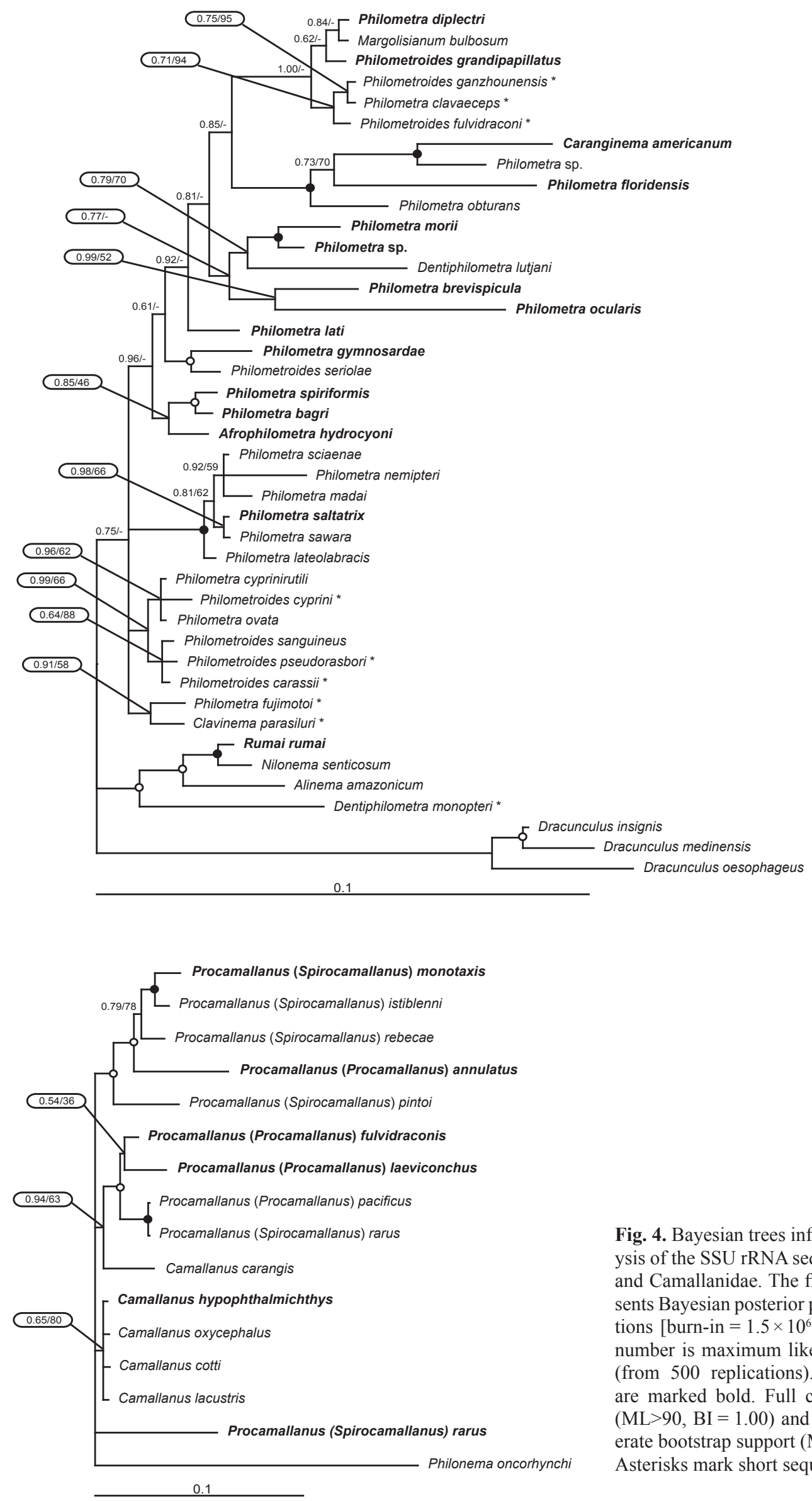

Fig. 4. Bayesian trees inferred from phylogenetic analysis of the SSU rRNA sequences dataset Philometridae and Camallanidae. The first number near nodes represents Bayesian posterior probability (for $5 \times 10^{6}$ generations [burn-in $=1.5 \times 10^{6}$ and $\left.2 \times 10^{6}\right]$ ) and the second number is maximum likelihood (ML) bootstrap value (from 500 replications). Newly acquired sequences are marked bold. Full circles illustrate high support $(\mathrm{ML}>90, \mathrm{BI}=1.00)$ and empty circles illustrate moderate bootstrap support $(\mathrm{ML}=70-90, \mathrm{BI}=0.80-0.99)$. Asterisks mark short sequences. 


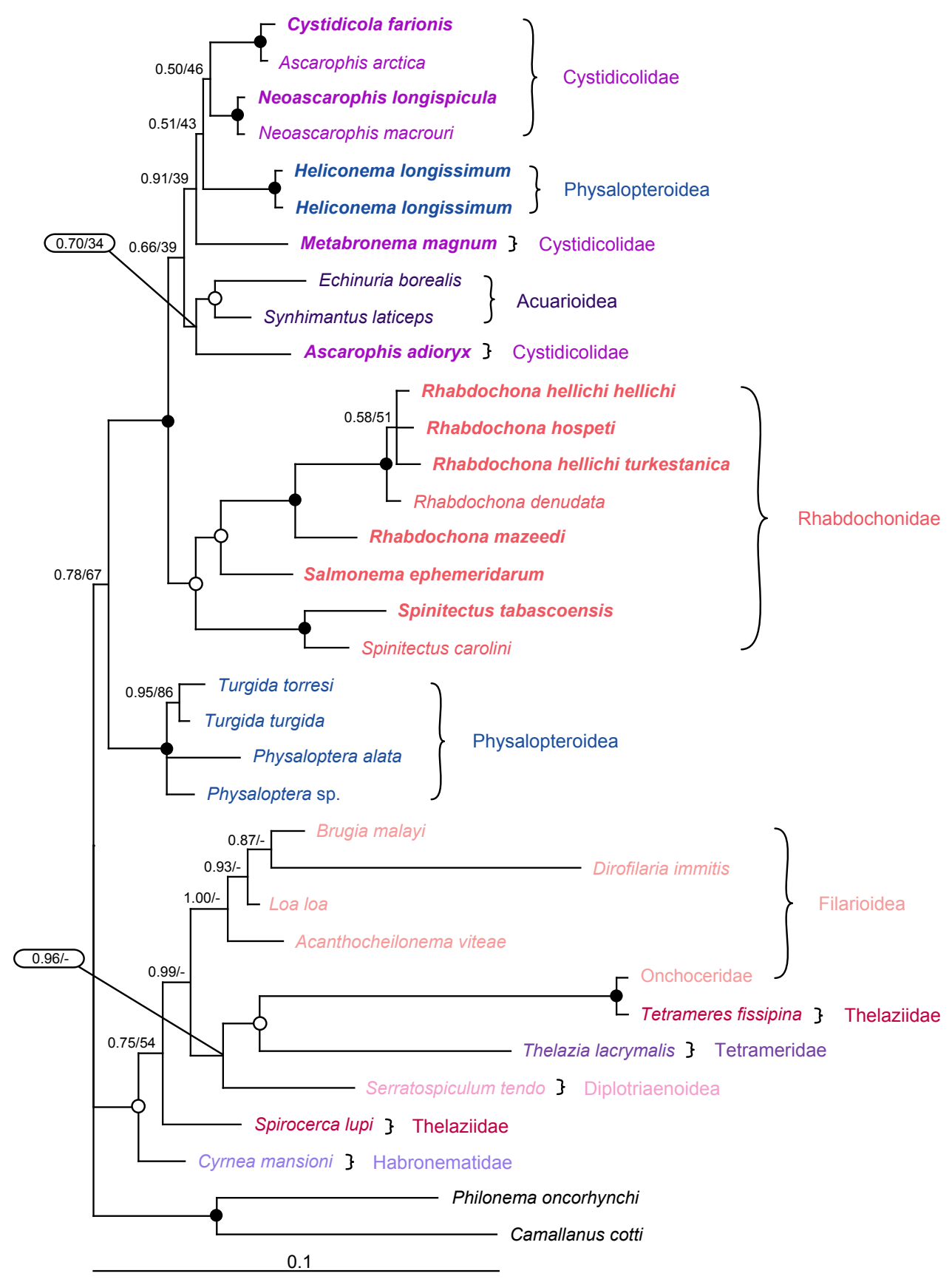

Fig. 5. Bayesian tree inferred from phylogenetic analysis of the SSU rRNA sequences dataset Spirurina. The first number near nodes represents Bayesian posterior probability (for $5 \times 10^{6}$ generations [burn-in $\left.=2 \times 10^{6}\right]$ ) and the second number is maximum likelihood (ML) bootstrap value (from 500 replications). Newly acquired sequences are marked bold. Full circles illustrate high support $(\mathrm{ML}>90, \mathrm{BI}=1.00)$ and empty circles illustrate moderate bootstrap support $(\mathrm{ML}=70-90, \mathrm{BI}=0.80-0.99)$.

Physalopteroidea (family Physalopteridae) as well as Thelazioidea. An interesting aspect of result is that the part of the superfamily Physalopteroidea (with the species Heliconema longissimum) splits off from related genera (Physaloptera sp., Turgida sp.) occurring on the basis of this branch and integrates between Habronematoidea and Acuarioidea. The second branch includes representatives of paraphyletic superfamilies Filarioidea (family Onchocercidae) (Fig. 5), Thelazioidea, Habronematoidea and Diplotriaenoidea (family Diplotriaenidae), each with only one species studied. Fig. 5 illustrates paraphyly of the families Cystidicolidae and Thelaziidae, monophyly of the family Rhabdochonidae, and families Tetrameridae and Habronematidae represented by only a single species. This conclusion is corroborated by the results of this analysis, in which the genera Neoascarophis, Spinitectus (Cystidicolidae), Rhabdochona (Rhabdochonidae) and the species Heliconema longissimum (Physalopteridae) are monophyletic and well supported, in contrast to the genus Ascarophis, which is paraphyletic. 


\section{DISCUSSION}

Present studies on the molecular phylogeny of nematodes are noted for the considerable imbalance of studied samples. Whereas the majority of the included nematodes is represented by groups of free-living species and plant parasites, the number of sequenced nematodes parasitizing vertebrates comprises only a negligible part in recent molecular-phylogenetic studies, such as in the group designated as 'clade III' by Blaxter et al. (1998). This sample bias decreases the utility of these studies for creating new classification systems within the framework of the phylum Nematoda (De Ley and Blaxter 2002, 2004, Holterman et al. 2006, Nadler et al. 2007, van Megen et al. 2009).

The present study substantially increases the number of sequenced nematode species parasitizing vertebrates, mainly fish. In total, sequences were obtained from 36 nominal species and subspecies belonging to 10 families, mostly of the superfamilies Camallanoidea, Dracunculoidea, Habronematoidea and Thelazioidea. Furthemore in this study, representatives of the families Daniconematidae (Mexiconema africanum) and Quimperiidae (Paraquimperia africana) are included for the first time, as well as species of previously unstudied genera Cystidicola (C. farionis), Metabronema (M. magnum) and Salmonema (S. ephemeridarum) in Cystidicolidae, Afrophilometra (A. hydrocyoni), Caranginema (C. americanum) and Rumai (R. rumai) in Philometridae and Esocinema (E. bohemicum) in Skrjabillanidae. In many of these cases, rare samples of recently described new nematode species were analysed.

The present molecular-phylogenetic analysis on the basis of SSU rRNA genes made possible a new evaluation of a number of relationships among these parasites. It can be deduced from the obtained results that Cucullanidae (Cucullanus baylisi and Truttaedacnitis truttae [= Cucullanus (Truttaedacnitis) truttae]) forms a basal group of the Spirurina proposed by De Ley and Blaxter (2002). Anderson et al. (2009) placed Cucullanidae and Quimperiidae in the superfamily Seuratoidea, the representatives of which are noted for some archaic characters. According to the Russian system of nematodes, these groups are ranked within the suborder Cucullanata, being considered an interface between Ascaridata and Spirurata (Ivashkin and Khromova 1976). Species of Cucullanidae and Quimperiidae are intestinal parasites of cold-blooded vertebrates, mainly fishes, as well as amphibians and reptiles (tortoises). Goezia spinulosa is located on the same branch as Goezia pelagia, thus confirming the placement of the genus in the superfamily Ascaridoidea of the order Ascaridida, as in the conception of De Ley and Blaxter (2004), within the family Raphidascarididae (representetives are intestinal parasites of fish).

Camallanoidea and Dracunculoidea constitute a monophyletic group creating two distinct evolutionary lines, which indicates some remote affinities of both groups.
Species of these groups exhibit a similar ontogenetic development, characterised by ovoviviparity, and intermediate hosts are crustaceans mainly of the suborder Copepoda or less often Branchiura (fish lice) (Anderson 2000). A notable result of this study, already indicated by Wijová et al. (2006), is that Philonema sp. along with representatives of Skrjabillanidae and Daniconematidae form a separate group splitting off other Dracunculoidea. Chitwood (1937) placed the genus Philonema in Philometridae, but noticed that it differs from other genera by the presence of multinucleate oesophageal glands. Ivashkin et al. (1971) established an independent subfamily Philoneminae within Philometridae on the basis of multinucleate oesophageal glands and cone-shaped caudal body end. This classification was followed by Chabaud (1975). Later, however, Moravec (2006) transferred Philonema from Philometridae to Micropleuridae (subfamily Micropleurinae), based on the oesophageal structure and general morphology (in addition, Philoneminae was not recognised by him). However, the results of this molecular study show that the genera Philonema and Micropleura form two different lines (see also Wijová et al. 2006), which could be taken for two different families in the system of dracunculoid nematodes. Similar results were also obtained by Nadler et al. (2007). Therefore, it is possible to raise the subfamily Philoneminae Ivashkin, Sobolev et Khromova, 1971 to the family rank Philonemidae and to consider it valid.

A very important result of the present work is the establishment of the phylogenetic position of Mexiconema as the first representative of Daniconematidae. It shows that these nematodes fall into the same evolutionary line as typical representatives of Skrjabillanidae (Molnaria [= Kalmanmolnaria] and Skrjabillanus), which is placed on the same branch with Philoneminae. On the contrary, the position of Esocinema, also established within Skrjabillanidae, is more distant from typical skjabillanid genera than Mexiconema. Moravec (2006) accommodated Esocinema into the separate subfamily Esocineminae, whereas the nominotypical subfamily Skrjabillaninae contains Kalmanmolnaria (syn. Molnaria), Sinoichthyonema and Skrjabillanus. All these genera include tissue parasites of fishes, developing via blood-sucking branchiurids, whereas the monophyletic line Philoneminae has representatives also parasitizing freshwater fishes, but their development is with the participation of copepod intermediate hosts.

As evidenced by these results, Philometridae is paraphyletic. Phylogenetic trees contain great numbers of molecular-studied species (32), nearly a half of which (15) is first reported in this study, including some representatives of the previously uncharacterised genera Afrophilometra, Caranginema and Rumai. Species of Philometra and Philometroides are paraphyletic, which may indicate that these genera are not natural and thus not reflecting true phylogenetic relationships. However, this situation is not the case for Alinema, Nilonema and Rumai, species of which occur in freshwater fishes in South America (Alinema, Rumai) or South America and Africa (Nilonema). In 
contrast to other philometrids, these species are characterised by a somewhat different structure of the oesophagus, certain specific features in the structure of cephalic end, or even the presence of a functional vulva in Alinema, which is otherwise atrophied in all other adult philometrids.

The next line is represented by species of Philomet$r a$ and Afrophilometra from freshwater fishes in Africa. Despite their different sites of infection within the host (body cavity in $P$. lati, gill arches and covers in $P$. spiriformis, subcutaneous tissue in P. bagri, fins in A. hydrocyoni - see Moravec et al. 2009) and phylogenetically distant hosts (Characiformes, Perciformes and Siluriformes), these nematodes constitute a separate evolutionary line, but only in one analysis. This group fragments in the two other trees. Another group is formed by three species from European freshwater cyprinids: Philometra cyprinirutili and Philometra ovata parasitic in the abdominal cavity, and Philometroides sanguineus parasitic in fins. As already indicated by Wijová et al (2006), the phylogenetic tree involving philometrid representatives with short sequences shows that also three Asian species, Philometroides cyprini, Philometroides carassii and Philometroides pseudorasbori from freshwater cyprinids, belong to this group. A sister group to them is formed by two species also from Asia, Philometra fujimoioi from freshwater catfishes (Siluriformes) and Clavinema parasiluri from freshwater snakeheads (Perciformes).

The cluster comprising Philometra lateolabracis, P. madai, P. nemipteri, P. saltatrix, $P$. sawara and $P$. sciaenae represents species from marine perciform fishes, all parasites of gonads, mostly from the Pacific Ocean near Japan: only P. saltatrix is found in the eastern and western parts of the Atlantic near North America and Europe (Mediterranean Sea). Here, the clustering appears to be due to their infection of the same location within the host than geographic isolation or dependence on a type of host, even though another congeneric species, $P$. floridensis from the gonads of a brackish-water perciform fish, is genetically different and is a part of the other evolutionary line. Also the other two main lines are represented by species largely from marine perciform fishes, which in contrast parasitize under the skin of head, in the oral cavity, fins or in eye orbits. On the other branch, there are Caranginema americanum and Philometra sp., whose sister group is constituted of two species, Philometra floridensis and P. obturans (the latter occurring in the circulatory system of European pikes). A sister group to the above-mentioned branch is formed by the species Philometra diplectri, Philometroides grandipapillatus and Margolisianum bulbosum (gen. et sp. inquirendae - mixed two species, Philometra overstreeti + Philometroides paralichthydis - see Moravec and de Buron 2006). All these species occur in marine fishes in the West Atlantic. A sister clade to this cluster is formed by a group of freshwater species made up of Philometra clavaeceps, Philometroides fulvidraconi and P. ganzhounensis
(= Philometroides pseudaspii), all parasites of East and Central Asian freshwater fishes (Russian Far East, China, Mongolia). Whereas the first species is parasitic in the fish abdominal cavity, the other species are parasites of fish subcutaneous tissues. The second line is represented by the species Philometra morii and Philometra sp. (both forms represented by two morphologically closely related species parasitizing fishes of the family Serranidae) and the phylogenetically rather more distant Dentiphilometra lutjani, and a sister group of Philometra brevispicula and Philometra ocularis. All these species, except for the last, are distributed in the West Atlantic region (Gulf of Mexico, Caribbean Sea), whereas P. ocularis is found in the Pacific (Japan, New Caledonia).

The remaining group is formed by two species, both from marine perciform fishes of the family Scombridae, of which Philometra gymnosardae parasitizes the body cavity of tuna fishes in the Indian Ocean (Maldive Islands), whereas Philometroides seriolae infects the musculature of fishes of the genus Seriola in the Pacific Ocean (Japan). Even though the speciation of these parasites in dependence on their hosts and geographical insulation might have been involved in this case, it is more likely with regard to the small number of studied species that a casual relationship of hosts of these nematodes was concerned. It is remarkable that the family Philometridae, along with Dracunculidae and Micropleuridae, forms a monophyletic group. It is possible to judge from the phylogenetic tree and the type of hosts of recent representatives of these families (Moravec 2006) that Micropleuridae (parasites of sharks, amphibians and reptiles, mainly crocodiles) initially split off first from the line leading to Philometridae (parasites of fishes) and Dracunculidae (parasites of warm-blooded vertebrates) only later.

The superfamily Camallanoidea (with only one family Camallanidae) is monophyletic and forms a sister group to Dracunculoidea. Whereas all freshwater species of $\mathrm{Ca}$ mallanus comprise one phylogenetic line, Camallanus carangis from marine fishes points affinities to the other line leading to freshwater and marine forms of Procamallanus. Since representatives of Procamallanus (including subgenera Procamallanus and Spirocamallanus) appear in different phylogenetic lines represented by species from marine and freshwater fishes from different continents, it can be supposed that these genera, i.e., Camallanus and Procamallanus, are formal taxa not reflecting true phylogenetic relationships. Surprisingly, the nematodes Procamallanus (Spirocamallanus) rarus from two different hosts from Peru appear in different branches. In this case, a wrong species determination of the specimens in question could be the cause.

The presently studied spirurine nematodes belong to three families, Cystidicolidae (Habronematoidea), Rhabdochonidae (Thelazioidea) and Physalopteridae (Physalopteroidea), according to both the current system of nematodes based on morphology (Gibbons 2010) 
and the molecular system (De Ley and Blaxter 2004). Nevertheless, Nadler et al. (2007) create the new superfamily Spiruroidea for Cystidicolidae. However, it follows from the phylogenetic tree that, even if representatives of these three families from fishes are placed on one branch, other species of the same superfamilies from birds and mammals occur in other phylogenetic lines and are thus paraphyletic. Hence it is evident that Habronematoidea, Thelazioidea and Physalopteroidea, and also the later-established Spiruroidea, are not natural taxa corresponding to mutual relationships. According to the morphological system, all representatives of the hitherto family Physalopteridae from fishes belong to the subfamily Proleptinae (Moravec et al. 2007, Anderson et al. 2009). It seems that in the future it will be necessary to elevate this subfamily to the rank of an independent family, whereas the actual existence of the superfamily Physalopteroidea remains unclear.

It follows from the results of the present analysis that Proleptinae belongs to the same cluster with Cystidicolidae and Rhabdochonidae from fishes, but also with Acuarioidea from birds. The phylogenetic tree confirms that species of Cystidicolidae and Rhabdochonidae from fishes occur in two distinct lines, of which Rhabdochonidae (Rhabdochona) is monophyletic and placed only in one of them; however, three species of the genera ( Salmonema and Spinitectus) assigned so far to Cystidicolidae are also found in it. A sister group to this branch is mostly formed by representatives of Cystidicolidae along with those of Acuarioidea and the fish-parasitizing Physalopteroidea. Notable are also the mutual distance of Ascarophis arctica and Ascarophis adioryx and the location of Metabronema magnum. Whereas Metabronema and Cystidicola include swimbladder parasites of fishes, species of Ascarophis and Neoascarophis are parasites of the digestive tract (stomach). An interesting finding is also the location of Salmonema ephemeridarum, a freshwater parasite of salmonids whose morphology and biology are very similar to those of the marine species of Ascarophis. In the second line, a marked separation of Rhabdochona mazeedi from the other studied representatives of this genus is observed; this evidently indicates that this species belongs to the subgenus Globochona, whereas others to the nominotypical subgenus Rhabdochona. Such a posi- tion of the representative of Globochona suggests that this taxon should be elevated to genus. The phylogenetic tree also shows a genetic difference between the population of Rhabdochona hellichi in European barbels (Barbus) and that from fishes of the genus Schizothorax in the Oriental Region; both populations are now taken for independent subspecies $R$. hellichi hellichi and $R$. hellichi turkestanica (see Moravec et al. 2010), but may actually represent separate species.

In the herein established phylogenetic trees, low-supported branches are found in one or both analyses. Furthermore, topology mutually differs in several cases, as well as the formation of polytomy. A possible solution of this problem could be the involvement of other, more variable genes (e.g., LSU, ITS1 and ITS2) in the analyses, which might bring phylogenetically relevant information.

Acknowledgements. Thanks are due to the following persons for kindly providing the specimens used in this study: M. Bakenhaster, St. Petersburg, USA (Caranginema americanum, Philometra brevispicula, P. diplectri, P. floridensis, P. morii, Philometra sp. from Mycteroperca microlepis, Philometroides grandipapillatus); I. de Buron, Charleston, USA (Philometra saltatrix); A. Gustinelli, Bologna, Italy (Cystidicola farionis); M. Jirků, České Budějovice, Czech Republic (Afrophilometra hydrocyoni, Mexiconema africanum, Philometra bagri, P. lati, P. spiriformis); J.-L. Justine, Paris/Nouméa, France/New Caledonia (Ascarophis adioryx, Metabronema magnum, Philometra ocularis, Procamallanus annulatus, P. monotaxis); S. Klimpel, Düsseldorf, Germany (Neoascarophis longispicula); R. Konečný, Vienna, Austria (Philometra gymnosardae); K. Nagasawa, Hiroshima, Japan (Heliconema longissimum); G. Salgado-Maldonado, Mexico City, Mexico (Spinitectus tabascoensis); C.P. Santos, Rio de Janeiro, Brazil (Goezia spinulosa, Rumai rumai); T. Scholz, České Budějovice, Czech Republic (Cucullanus baylisi, Procamallanus laeviconchus, P. rarus, Rhabdochona hellichi turkestanica, R. hospeti, R. mazeedi); S.G. Sokolov, Moscow, Russia (Esocinema bohemicum); H. Taraschewski, Karlsruhe, Germany (Heliconema longissimum, Paraquimperia africana); and S. Wu, Wuhan, China (Camallanus hypophthalmichthys, Procamallanus fulvidraconis). We would also like to thank members of the M. Oborník laboratory, T. Scholz and J. Lukeš for support and discussion. Special thanks are given to Hassan Hashimi for revising the English. This study was supported by grant No. 524/06/0170 from the Grant Agency of the Czech Republic and by the research projects of the Institute of Parasitology, BC ASCR (Z60220518 and LC522).

\section{REFERENCES}

Anderson R.C. 2000: Nematode Parasites of Vertebrates. Their Development and Transmission. 2nd Ed. CABI Publishing, Wallingford, UK, $650 \mathrm{pp}$.

Anderson R.C., Chabaud A.G., Willmott S. 1974-1983: Keys to the Nematode Parasites of Vertebrates. Nos. 1-10. Commonwealth Bureaux of Agriculture, Farnham Royal, Bucks, UK.

Anderson R.C., Chabaud A.G., Willmott S. 2009: Keys to the Nematode Parasites of Vertebrates. Archival Volume. CAB International, Wallingford, UK, $463 \mathrm{pp}$.
Blaxter M.L., De Ley P., Garey J.R., Liu L.X., Scheldeman P., Vierstraete A., Vanfleteren J.P., Mackey L.Y., Dorris M., Frisse L.M., Vida J.T., Thomas W.K. 1998: A molecular evolutionary framework for the phylum Nematoda. Nature 392: $71-75$.

Chabaud A.G. 1974: Class Nematoda. Keys to subclasses, orders and superfamilies. In: R.C. Anderson, A.G. Chabaud and S. Willmott (Eds.), CIH Keys to Nematode Parasites of Verte- 
brates. No. 1. Commonwealth Bureaux of Agriculture, Farnham Royal, Bucks, UK, pp. 6-17.

Chabaud A.G. 1975: Keys to genera of the order Spirurida. Part 1. Camallanoidea, Dracunculoidea, Gnathostomatoidea, Physalopteroidea, Rictularoidea and Thelazioidea. In: R.C. Anderson, A.G. Chabaud and S. Willmott (Eds.), CIH Keys to the Nematode Parasites of Vertebrates, No. 3. Commonwealth Bureaux of Agriculture, Farnham Royal, Bucks (UK), 27 pp.

Chitwood B.G. 1933: A revised classification of the Nematoda. J. Parasitol. 20: 131.

Chitwood B.G. 1937: A revised classification of the Nematoda. In: Anonym (Ed.), Papers on Helminthology. 30 Year Jubilee K.I Skryabin. All-Union Lenin Academy of Agricultural Sciences, Moscow, pp. 67-79.

Chitwood B.G. 1950: An outline classification of the Nematoda. In: B.G. Chitwood and M.B. Chitwood (Eds.), Introduction to Nematology. University Park Press, Baltimore, Maryland, pp. $12-25$.

De Ley P., Blaxter M.L. 2002: Systematic position and phylogeny. In: D.L. Lee (Ed.), The Biology of Nematodes. Tailor \& Francis, London and New York, pp. 1-30.

De Ley P., Blaxter M.L. 2004: A new system for Nematoda: combining morphological characters with molecular trees, and translating clades into ranks and taxa. Nematol. Monogr. Perspect. 2: 633-653.

Gibbons L.M. 2010: Keys to the Nematode Parasites of Vertebrates. Supplementary Volume. CABI, Wallingford, UK, $416 \mathrm{pp}$.

Hall T.A. 1999: BioEdit: a user-friendly biological sequence alignment editor and analysis program for Windows 95/98/NT. Nucleic Acids Symp. Series 41: 95-98.

Holterman M., van der Wurff A., van den Elsen S., van Megen H., Bongers T., Holovachov O., Bakker J., Helder J. 2006: Phylum-wide analysis of SSU rDNA reveals deep phylogenetic relationships among nematodes and accelerated evolution toward crown clades. Mol. Biol. Evol. 23: 1798-1800.

Huelsenbeck J.P., Ronquist F., Nielsen R., Bollback J.P. 2001: Bayesian inference of phylogeny and its impact on evolutionary biology. Science 294: 2310-2314.

Ivashrin V.M., Khromova L.A. 1976: [Cucullanata and Gnathostomatata of Animals and Man and the Diseases Caused by Them. Essentials of Nematodology 27.] Nauka, Moscow, 436 pp. (In Russian.)

Ivashin V.M., Sobolev A.A., Khromova L.A. 1971: [Camallanata of Animals and Man and the Diseases Caused by Them. Essentials of Nematodology 22.] Nauka, Moscow, 388 pp. (In Russian.)

Katoh K., Misawa K., Kuma K., Miyata T. 2002: MAFFT: a novel method for rapid multiple sequence alignment based on fast Fourier transform. Nucleic Acids Res. 30: 3059-3066.

Meldal B.H.M., Debenham N.J., De Ley P., De Ley I.T., Vanfleteren J.R., Vierstraete A.R., Bert W., Borgonie G., Moens T., Tyler P.A., Austen M.C., Blaxter M.L., Rogers A.D., Lambshead P.J.D. 2007: An improved molecular phylogeny of the Nematoda with special emphasis on marine taxa. Mol. Phylogenet. Evol. 42: 622-636.

Moravec F. 1994: Parasitic Nematodes of Freshwater Fishes of Europe. Academia and Kluwer Academic Publishers, Prague and Dordrecht, Boston, London, $473 \mathrm{pp}$.

Moravec F. 2004: Some aspects of the taxonomy and biology of dracunculoid nematodes parasitic in fishes: a review. Folia Parasitol. 51: 1-13.
Moravec F. 2006: Dracunculoid and Anguillicoloid Nematodes Parasitic in Vertebrates. Academia, Prague, 634 pp.

Moravec F. 2007: Some aspects of the taxonomy and biology of adult spirurine nematodes parasitic in fishes: a review. Folia Parasitol. 54: 239-257.

Moravec F., Charo-Karisa H., Jirkư M. 2009: Philometrids (Nematoda: Philometridae) from fishes of Lake Turkana, Kenya, including two new species of Philometra and erection of Afrophilometra gen. n. Folia Parasitol. 56: 41-54.

Moravec F., De Buron I. 2006: Two new species of philometrid nematodes (Nematoda: Philometridae) from the southern flounder Paralichthys lethostigma in the estuaries of South Carolina, USA. Folia Parasitol. 53: 139-146.

Moravec F., Molnár K., SzéKely C. 1998: Lucionema balatonense gen. et sp. n., a new nematode of a new family Lucionematidae fam. n. (Dracunculoidea) from the swimbladder of the European pikeperch, Stizostedion lucioperca (Pisces). Folia Parasitol. 45: 56-61.

Moravec F., Scholz T., Ash A., Kar P.K. 2010: New data on the morphology and taxonomy of three species of Rhabdochona (Nematoda: Rhabdochonidae) parasitizing fishes in India. Folia Parasitol. 57: 295-306.

Moravec F., Taraschewsi i H., Anantaphruti M.T., Maipanich W., Laoprasert T. 2007: Heliconema longissimum (Ortlepp, 1923) (Nematoda: Physalopteridae) in Thailand, with remarks on the taxonomy of the Proleptinae Schulz, 1927. Syst. Parasitol. 66: 73-80.

Nadler S.A., Carreno R.A., Mejía-Madrid H., Ullberg J., Pagan C., Houston R., Hugot J.-P. 2007: Molecular phylogeny of clade III nematodes reveals multiple origins of tissue parasitism. Parasitology 134: 1421-1442.

Posada D., Crandall K.A. 1998: Modeltest: testing the model of DNA substitution. Bioinformatics 14: 817-818.

Rudolphi C.A. 1808: Entozoorum Sive Vermium Intestinalium. Historia Naturalis, Vol. 1. Amstelaedami, 527 pp.

Sambrook J., Russell D.W. 2001: Molecular Cloning: A Laboratory Manual. 3rd Ed. Chapter 6. Protocol 1: 6.9-6.11. Cold Spring Harbor Laboratory Press, New York.

Shimodaira H. 2004: Approximately unbiased tests of regions using multistep-multiscale bootstrap resampling. Ann. Stat. 32: 2616-2641.

Shimodaira H., Hasegawa M. 2001: CONSEL: for assessing the confidence of phylogenetic tree selection. Bioinformatics 17: $1246-1247$

Stamatakis A. 2006: RAxML-VI-HPC: maximum likelihoodbased phylogenetic analyses with thousands of taxa and mixed models. Bioinformatics 22: 2688-2690.

van Megen H., van den Elsen S., Holterman M., Karssen G., Mooyman P., Bongers T., Holovachov O., Bakker J., Helder J. 2009: A phylogenetic tree of nematodes based on about 1200 full-length small subunit ribosomal DNA sequences. Nematology 11: 927-950.

Wijová M., Moravec F., Horák A., Lukeš J. 2006: Evolutionary relationships of Spirurina (Nematoda: Chromadorea: Rhabditida) with special emphasis on dracunculoid nematodes inferred from SSU rRNA gene sequences. Int. J. Parasitol. 36: $1067-1075$.

Yamaguti S. 1961: Nematodes of Vertebrates. Systema Helminthum 3. Interscience Publishers, New York - London, 1261 pp. 